\title{
Trans-acting antisense RNAs mediate transcriptional gene cosuppression in S. cerevisiae
}

\author{
Jurgi Camblong, ${ }^{1}$ Nissrine Beyrouthy, Elisa Guffanti, Guillaume Schlaepfer, Lars M. Steinmetz, ${ }^{2}$ \\ and Françoise Stutz ${ }^{3}$
}

Department of Cell Biology and NCCR "Frontiers in Genetics" Program, University of Geneva, 1211 Geneva 4, Switzerland

\begin{abstract}
Homology-dependent gene silencing, a phenomenon described as cosuppression in plants, depends on siRNAs. We provide evidence that in Saccharomyces cerevisiae, which is missing the RNAi machinery, protein coding gene cosuppression exists. Indeed, introduction of an additional copy of PHO84 on a plasmid or within the genome results in the cosilencing of both the transgene and the endogenous gene. This repression is transcriptional and position-independent and requires trans-acting antisense RNAs. Antisense RNAs induce transcriptional gene silencing both in cis and in trans, and the two pathways differ by the implication of the Hda1/2/3 complex. We also show that trans-silencing is influenced by the Set1 histone methyltransferase, which promotes antisense RNA production. Finally we show that although antisense-mediated cis-silencing occurs in other genes, transsilencing so far depends on features specific to PHO84. All together our data highlight the importance of noncoding RNAs in mediating RNAi-independent transcriptional gene silencing.
\end{abstract}

[Keywords: Antisense RNA; cis and trans transcriptional gene silencing; PHO84; cosuppression; RNAi-independent TGS; noncoding RNA; S. cerevisiae]

Supplemental material is available at http://www.genesdev.org.

Received January 15, 2009; revised version accepted May 18, 2009.

Eukaryotic gene expression is a complex process regulated at multiple steps from transcription initiation to protein degradation. For years, transcription factors recognizing specific DNA-binding sites have been considered the main regulators of gene expression. More recently, the discovery of the histone code revealed that transcription is also tightly regulated by histone modifications (Strahl and Allis 2000; Mellor 2006; Mellor et al. 2008). Importantly, these modifications not only regulate transcription within euchromatin but also participate in transcriptional gene silencing (TGS) at heterochromatic loci. Heterochromatic gene silencing has been most extensively described in Schizosaccharomyces pombe, where siRNAs originating from these regions target the RITS complex to induce repressive histone modifications (Volpe et al. 2002; for review, see Buhler and Moazed 2007). Although, the complete RNAi machinery is absent in Saccharomyces cerevisiae (Aravind et al. 2000), RNA-mediated TGS within euchromatin has been

Present addresses: ${ }^{1}$ Sir William Dunn School of Pathology, University of Oxford, Oxford OX1 3RE, United Kingdom; ${ }^{2}$ European Molecular Biology Laboratory, Meyerhofstrasse 1, 69117 Heildelberg, Germany. ${ }^{3}$ Corresponding author.

E-MAIL Francoise.Stutz@unige.ch; FAX 21-314-40-95.

Article is online at http://www.genesdev.org/cgi/doi/10.1101/gad.522509. recently reported (Camblong et al. 2007; Berretta et al. 2008; Houseley et al. 2008). In particular, we showed that stabilization of PHO84 antisense RNAs, escaping degradation by the nuclear exosome in the absence of the Rrp6 exoribonuclease or during chronological aging, leads to PHO84 TGS via a mechanism implicating the Hda1/2/3 histone deacetylase (Camblong et al. 2007). In addition, histone modifications within heterochromatic rDNA regions were also shown to be influenced by the accumulation of noncoding RNAs from the nontranscribed rDNA spacer regions (NTS) (Houseley et al. 2007; Vasiljeva et al. 2008). Together these observations suggest the existence of an alternative, potentially conserved pathway for RNA-dependent chromatin modifications in $S$. cerevisiae.

Earlier work in $S$. pombe indicated that siRNAs primarily act in cis to target heterochromatic TGS (Buhler et al. 2006). Similarly, the fact that in S. cerevisiae antisense RNA accumulation in the progeny of old cells is paralleled by a decrease in Rrp6 occupancy on PHO84 suggested the view that antisense RNAs are degraded by this exosome component at their site of synthesis, and might consequently act in cis (Camblong et al. 2007). However, recent data from $S$. pombe indicate that siRNAs produced in trans can also be effective in TGS but still require antisense RNA to be produced in cis (Iida et al. 
2008). Moreover, like in higher eukaryotes, Ty1 expression and mobility are regulated by trans-acting antisense RNAs in S. cerevisiae (Berretta et al. 2008). Related mechanisms may therefore control retrotransposon spreading in all these organisms, whether or not they harbor the RNAi machinery (Girard and Hannon 2008). This finding suggests the interesting possibility that, like in higher eukaryotes, trans-acting noncoding RNAs may mediate homology-dependent silencing of protein coding genes in budding yeast.

To address this issue, we used PHO84 as a model gene to test whether antisense RNAs mediating PHO84 TGS in cis (Camblong et al. 2007) may also have the ability to act in trans. We found that expression of PHO84 antisense RNAs from an ectopic PHO84 gene copy is sufficient to trigger transcriptional silencing of both the endogenous and the ectopic genes. This robust reciprocal silencing is analogous to transcriptional cosuppression initially described in plants (Matzke and Matzke 1995a) and provides strong evidence that RNA-mediated protein coding gene cosuppression can occur through an RNAiindependent pathway in S. cerevisiae.

A

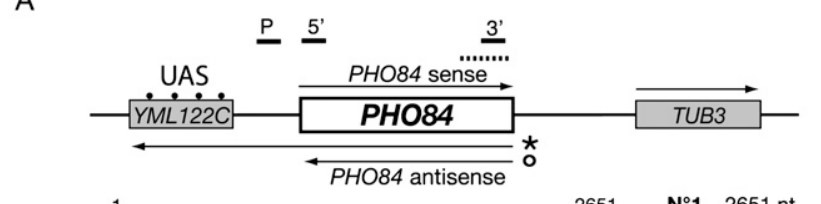

B

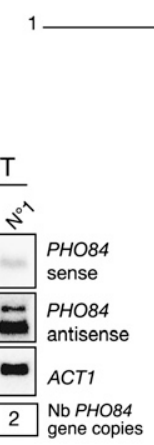

C

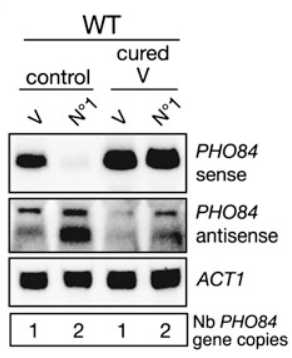

E

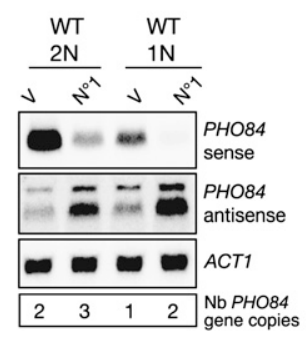

D
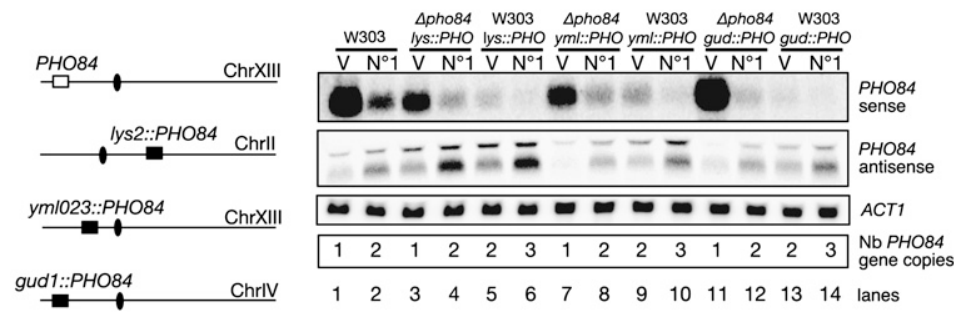

\section{Results}

\section{An additional PHO84 gene copy triggers PHO84 cosuppression}

In the course of our studies on the mechanism underlying transcriptional silencing of the PHO84 gene, encoding a high-affinity phosphate transporter (Persson et al. 1998), we cloned $\mathrm{PHO} 84$ on a centromeric plasmid (plasmid $\mathrm{N}^{\circ}$ 1) (Fig. 1A). When transformed in $\Delta$ pho84 strains, PHO84 on plasmid behaved as the endogenous gene (Supplemental Fig. 1; Camblong et al. 2007). However, unexpectedly, transformation of plasmid $\mathrm{N}^{\circ} 1$ into a wild-type strain led to a strong decrease in $\mathrm{PHO} 84$ sense transcripts paralleled by an increase in PHO84 antisense RNA levels (Fig. 1B). Plasmid loss from the transformed cells followed by transformation of an empty vector into the cured strains restored $\mathrm{PHO} 84$ sense RNA levels, demonstrating that the silencing is reversible and not due to the acquisition of mutations or gene conversions during the transformation process (Fig. 1C). These observations suggested that the presence of the $\mathrm{PHO} 84$ plasmid leads to $\mathrm{PHO} 84$

Figure 1. A PHO84 extra copy leads to cosuppression of PHO84 mRNA expression. (A) Map of the PHO84 locus. Arrows indicate the orientation of $\mathrm{PHO} 84$ sense, TUB3 sense, and PHO84 antisense transcripts. YML122C described as a hypothetical ORF contains four Pho4-binding sites (black circles) and encompasses the PHO84 upstream activating sequence (UAS). The line below indicates the $\mathrm{PHO} 84$ sequence $\mathrm{N}^{\circ} 1$ subcloned into the centromeric vector YCpLac111. The size of the insert is indicated on the right. Position 1 lies $105 \mathrm{bp}$ upstream of the beginning of hypothetical ORF YML122C (725 bp upstream of PHO84 ATG), and position 2651 is located at $+166 \mathrm{bp}$ downstream from the PHO84 stop codon. Filled rectangles indicate promoter $(\mathrm{P}), 5^{\prime}$ and $3^{\prime}$ regions of $\mathrm{PHO} 84$ amplified in ChIP analyses (Fig. 2). The dotted line corresponds to the $3^{\prime}$ region spanned by the ssRNA probe used in the blots below. $(B)$ Presence of an extra gene copy induces PHO84 cosuppression. Northern analysis of total RNA extracted from wild-type cells transformed with YCpLac111 empty vector (V) or YCpLac111 containing insert $\mathrm{N}^{\circ} 1\left(\mathrm{~N}^{\circ} 1\right)$. After transformation cells were exponentially grown in -LEU media for $24 \mathrm{~h}$. Total RNA was extracted and PHO84 sense and antisense RNAs detected with riboprobes mapping to PHO84 3' end. Membranes were rehybridized with an $A C T 1$ random labeled probe to control for equal loading. (C) PHO84 gene silencing is extra gene copy-dependent and reversible. Wild-type cells containing an empty vector $(\mathrm{V})$ or plasmid $\mathrm{N}^{\circ} 1$ were exponentially cultivated in -LEU for $24 \mathrm{~h}$. A fraction of the culture was diluted into YEPD medium to lose vector $(\mathrm{V})$ and $\mathrm{N}^{\circ} 1$ and the rest collected for RNA extraction. Cured cells were retransformed with empty vector followed by cultivation in -LEU and RNA extraction. PHO84 sense and antisense RNA levels from cells containing vector (V) or $\mathrm{N}^{\circ} 1$ (lanes 1,2$)$ were compared with those of cured cells retransformed with the empty vector (lanes 3,4) as in B. (D) PHO84 gene silencing is position-independent. Wild-type and $\Delta$ pho84 strains, each containing a PHO84 ectopic copy replacing either the LYS2 (lys::PHO), the YMLO23 (yml::PHO), or the GUD1 (gud::PHO) loci, were transformed with an empty vector (V) or PHO84 construct $\mathrm{N}^{\circ} 1$ and cultivated in -LEU medium followed by RNA extraction. Membranes were probed as in $B$. The chromosomal positions of endogenous (white square) and ectopic (black squares) PHO84 gene copies are diagrammed on the left. $(E)$ An extra gene copy induces silencing in diploid cells. PHO84 sense and antisense RNA levels in haploid and diploid wild-type cells transformed with an empty vector (V) or plasmid $\mathrm{N}^{\circ} 1\left(\mathrm{~N}^{\circ} 1\right)$ were analyzed as in $B$. In $B-E$, the numbers within the box indicate the number of $P H O 84$ gene copies in the genetically modified and transformed strains. 
cosuppression, a phenomenon originally described in transgenic plants and referring to homology-dependent gene silencing (Jorgensen 1995; Matzke and Matzke 1995b; Meyer and Saedler 1996).

To address whether PHO84 silencing would also occur following integration of a second $\mathrm{PHO} 84$ gene in the genome, an ectopic PHO84 copy was integrated at three different locations in a wild-type or a $\Delta$ pho84 strain, either in place of LYS2 (lys::PHO), YMLO23 (yml::PHO) or GUD1 (gud::PHO) (Fig. 1D). All three ectopic genes were expressed to similar or slightly lower levels compared with endogenous $\mathrm{PHO} 84$ when inserted in a $\Delta$ pho84 strain. However, when inserted in a wild-type strain, the presence of a second $\mathrm{PHO} 84$ gene in the genome resulted in $\mathrm{PHO} 84$ silencing, showing that one PHO84 extra copy is necessary and sufficient to trigger silencing. Note that in all cases, sense repression correlates with higher levels of antisense RNA (Fig. 1D, cf. lanes 3 and 5, lanes 7 and 9, and lanes 11 and 13). Interestingly, transformation of plasmid $N^{\circ} 1$ into the $\Delta$ pho84 strains containing just one PHO84 ectopic copy at the LYS2, YML083, or GUD1 loci also led to PHO84 sense mRNA silencing (Fig. 1D, cf. lanes 3 and 4, lanes 7 and 8 , and lanes 11 and 12), demonstrating that this silencing does not depend on PHO84 subtelomeric position. Consistently, loss of Ku70, Esc1, Sir2, and Hst1 involved in telomere silencing did not affect cosuppression (Supplemental Fig. 2; Supplemental Table 3; Taddei et al. 2004).

Finally, we compared expression levels in wild-type haploid and diploid cells. In the presence of the empty vector, PHO84 mRNA levels in wild-type diploid cells were about three times those of wild-type haploid cells. Importantly, the presence of plasmid $\mathrm{N}^{\circ} 1$ resulted in a sixfold reduction of PHO84 mRNA levels (Fig. 1E). These results indicate that silencing does not occur in the presence of two PHO84 copies in the context of a duplicated genome but is triggered by an extra gene copy, supporting the idea of a dose-dependent cosuppression.

\section{Silencing in trans is transcriptional and Hda1/2/3-independent}

To address at which level PHO84 expression is cosuppressed, chromatin immunoprecipitation (ChIP) experiments were performed to measure RNA polymerase II (RNA Pol II) occupancy at the 5' and $3^{\prime}$ ends of PHO84. Strikingly, RNA Pol II levels were dramatically reduced in the presence of plasmid $\mathrm{N}^{\circ} 1$ (Fig. 2A), indicating that the silencing is transcriptional. The repression is at the level of transcription initiation as TATA-binding protein (TBP) occupancy at the PHO84 promoter was strongly reduced (Fig. 2B). RNA Pol II and TBP occupancy was not further decreased in the absence of the Pho4 transcription factor, indicating that the PHO84 extra copy drastically affects transcription initiation (Fig. 2A,B).

Previously, we reported that PHO84 TGS resulting from chronological aging or from inactivation of the nuclear exosome is triggered by the $\mathrm{Hda} / 2 / 3 \mathrm{HDAC}$ complex (Camblong et al. 2007). In order to address whether this HDAC is also implicated in the cosuppres-
A

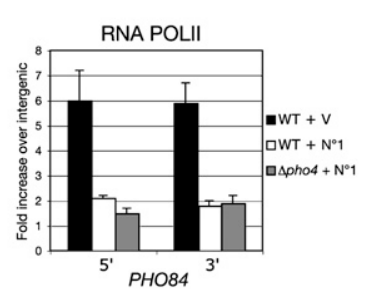

C

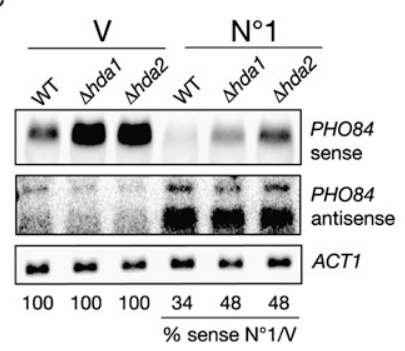

B

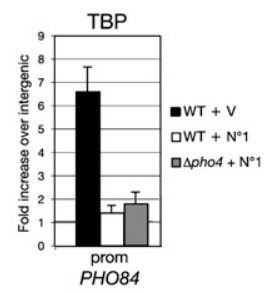

Figure 2. Silencing occurs at the level of transcription initiation and is Hdal/2/3-independent. $(A)$ ChIP analysis of RNA Pol II over the PHO84 gene. Wild-type and $\Delta$ pho4 strains transformed with an empty vector (V) or plasmid $\mathrm{N}^{\circ} 1\left(\mathrm{~N}^{\circ} 1\right)$ were grown in -LEU medium. RNA Pol II immunoprecipitated DNA was quantified by real-time PCR with PHO84-specific primers (Fig. 1A; Supplemental Table 2). The relative enrichment of the gene segments was expressed as the $n$-fold increase with respect to a nontranscribed intergenic sequence. Values derive from three independent experiments. $(B)$ ChIP analysis of TBP at the PHO84 promoter. The same chromatin extracts were immunoprecipitated with $\alpha$-TBP antibodies. The DNA was quantified by real-time PCR with primers specific for PHO84 promoter and normalized as in $A$. ChIP is measuring the level of association of both endogenous and plasmidic PHO84 with these factors. $(C)$ The Hdal/2/3 complex is not required for trans-silencing. PHO84 sense and antisense RNAs in wild-type, $\Delta$ hda1, and $\Delta$ hda2 strains transformed with an empty vector (V) or plasmid $\mathrm{N}^{\circ} 1$. Cell cultures and Northern blotting were performed as in Figure 1B. PHO84 sense mRNAs were quantified and normalized to $A C T 1$. For each strain, the levels of sense transcripts detected in presence of plasmid $\mathrm{N}^{\circ} 1$ were expressed as a percentage of those detected in presence of empty vector (bottom line).

sion mechanism, plasmid $\mathrm{N}^{\circ} 1$ was transformed in $\Delta$ hda1 and $\Delta$ hda2 strains. Importantly, PHO84 sense RNA levels were similarly reduced in wild-type and the two mutant strains, indicating that the $\mathrm{Hda} 1 / 2 / 3$ complex is not required for PHO84 cosuppression (Fig. 2C; Supplemental Fig. 3).

\section{Cosuppression requires a full $\mathrm{PHO} 84$ sequence from the upstream activating sequence (UAS) to the stop codon}

To further characterize the cosuppression mechanism, we aimed at defining the minimal PHO84 homologous sequence to be inserted in the plasmid copy for silencing to occur. Various PHO84 5' and 3' truncations of plasmid $\mathrm{N}^{\circ} 1$ were cloned (Fig. 3A) and first transformed into a $\Delta$ pho84 strain to define their expression in the absence of the endogenous $\mathrm{PHO} 84$ gene (Fig. 3B). While plasmids 
A

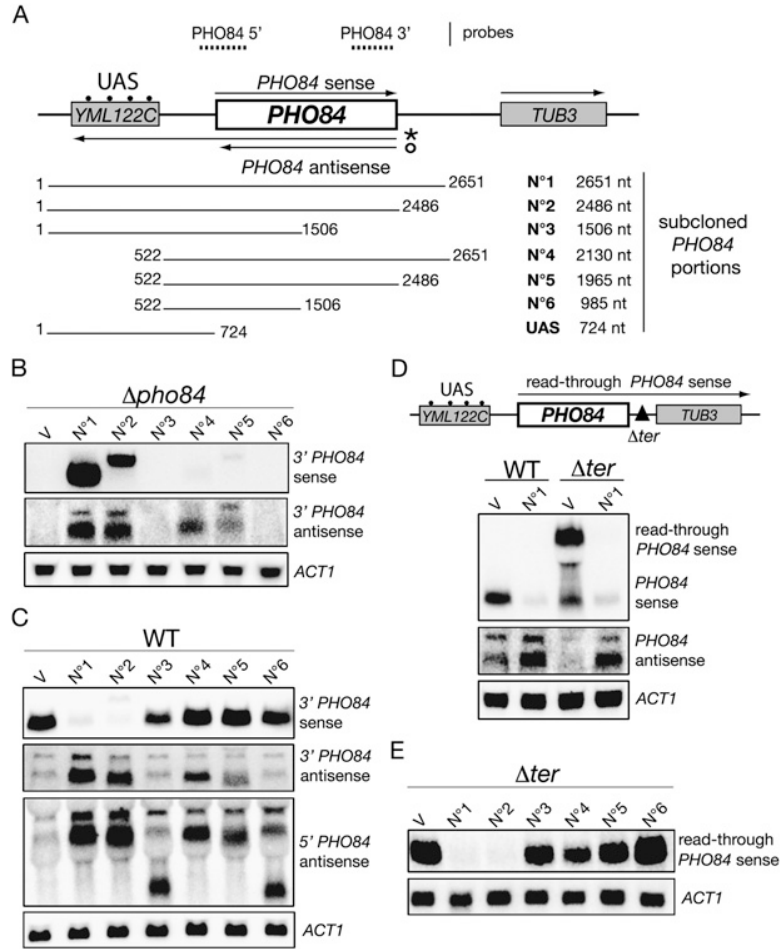

Figure 3. A PHO84 sequence containing both the UAS and ORF is required to trigger silencing. (A) Map of the $\mathrm{PHO} 84$ gene. The lines below indicate all $P H O 84$ portions $\left(\mathrm{N}^{\circ} 1-\mathrm{N}^{\circ} 6\right.$ and UAS) subcloned into the centromeric vector YCpLac111 or other expression vectors (see below). The size of each insert is indicated on the right. Position 1 lies $105 \mathrm{bp}$ upstream of YML122C (725 bp upstream of $P H O 84$ ATG), and position 2651 is located at $+166 \mathrm{bp}$ downstream from the $\mathrm{PHO} 84$ stop codon. Dotted lines correspond to $5^{\prime}$ and $3^{\prime}$ regions spanned by the ssRNA probes. $\mathrm{PHO} 84$ sense and antisense RNA expression in $\Delta p h o 84(B)$ or in wild-type cells $(C)$ transformed with $\mathrm{PHO} 84$ plasmids $\mathrm{N}^{\circ} 1-\mathrm{N}^{\circ} 6$. In both cases, sense RNAs were detected with a probe mapping to PHO84 3'end. Antisense RNAs were revealed with a probe mapping to PHO84 3' end in $\mathrm{B}$, or specific for PHO84 3' end or $5^{\prime}$ end (common to all six constructs) in C. (D) Deletion of $120 \mathrm{bp}$ within the PHO84 terminator (Ater strain) leads to the production of a long PHO84-TUB3 read-through transcript. Wildtype and $\Delta$ ter strains transformed with empty vector $(\mathrm{V})$ or plasmid $\mathrm{N}^{\circ} 1$ were analyzed as in Figure 1B. $(E)$ Expression of the PHO84-TUB3 read-through transcript in a $\Delta$ ter strain transformed with empty vector (V) or plasmids $\mathrm{N}^{\circ} 1-\mathrm{N}^{\circ} 6$.

$\mathrm{N}^{\circ} 1$ and $\mathrm{N}^{\circ} 2$ produce high levels of $\mathrm{PHO} 84$ sense mRNA, the latter makes a slightly longer transcript, presumably due to usage of an alternate $3^{\prime}$ processing signal in the vector. Transcripts of similar length but much lower abundance are encoded by plasmids $\mathrm{N}^{\circ} 4$ and $\mathrm{N}^{\circ} 5$ as these constructs lack the UAS. No sense transcripts could be detected in presence of plasmids $\mathrm{N}^{\circ} 3$ and $\mathrm{N}^{\circ} 6$ using the $3^{\prime}$ end-specific probe, but were revealed for $\mathrm{N}^{\circ} 3$ with a $5^{\prime}$ end-specific probe (Fig. 3A; data not shown). When transformed into a wild-type strain, both plasmids $\mathrm{N}^{\circ} 1$ and $\mathrm{N}^{\circ} 2$ induced a strong decrease in $\mathrm{PHO} 84$ sense RNA expression. Although plasmid $\mathrm{N}^{\circ} 3$ had a detectable effect, it was much weaker. In contrast, constructs $\mathrm{N}^{\circ} 4-\mathrm{N}^{\circ} 6$, missing the PHO84 UAS within YML122C, had no effect (Fig. 3C). Notably, all constructs produced detectable amounts of antisense RNAs and those derived from plasmids $\mathrm{N}^{\circ} 1$ and $\mathrm{N}^{\circ} 2$ were comparable in size to the endogenous transcripts (Fig. 3C, lanes 1-3).

To confirm these data, we generated a new strain in which the endogenous $\mathrm{PHO} 84$ sense transcripts are distinguishable from those produced by the transformed plasmid. This strain, called $\Delta$ ter, contains a 120 -base-pair (bp) deletion in the $3^{\prime}$ untranslated region (UTR) of the endogenous $\mathrm{PHO} 84$ locus, leading to a defect in transcription termination and production of long chimeric PHO84TUB3 sense RNAs (Fig. 3D). Transformation of the $\Delta$ ter strain with plasmids $\mathrm{N}^{\circ} 1$ or $\mathrm{N}^{\circ} 2$ led to the disappearance of the PHO84-TUB3 RNA, whereas plasmids $\mathrm{N}^{\circ} 3-\mathrm{N}^{\circ} 6$ did not substantially affect the levels of these transcripts, confirming the previous observations (Fig. 3C,E). These data therefore indicate that if antisense RNAs were players in trans-silencing (see below), they would have to be long and contain the region corresponding to the PHO84 UAS.

\section{Antisense RNA production is necessary for silencing in trans}

The silencing of $\mathrm{PHO} 84$ gene expression following transformation of plasmids $\mathrm{N}^{\circ} 1$ and $\mathrm{N}^{\circ} 2$ was paralleled by increased PHO84 antisense RNA levels (Fig. 3B,C), suggesting that antisense RNAs could not only trigger TGS in cis, but also mediate cosuppression in trans. To demonstrate the direct involvement of antisense RNAs in the PHO84 cosuppression phenomenon, the PHO84 sequence from plasmid $\mathrm{N}^{\circ} 1$ was subcloned behind a GAL promoter (GAL- ${ }^{\circ} 1$ ), such that antisense RNA production can be induced by shifting carbon source (Fig. 4). To test the efficiency of this system, we first asked whether we could manipulate silencing in cis by regulating antisense expression. Thus, $\Delta$ pho84 cells transformed with plasmid GAL- $\mathrm{N}^{\circ} 1$ were cultivated overnight in glucose or galactose-containing media. While cells cultivated in glucose expressed $\mathrm{PHO} 84$ sense RNAs, those grown in galactose did not, suggesting that antisense RNAs driven by the GAL promoter are efficient in silencing sense transcription in cis (Fig. 4A, lanes 1,2). Consistent with the previously described role of $\mathrm{Hda} 1 / 2 / 3$ in cis-silencing, PHO84 sense RNA expression was maintained in cells grown in galactose but lacking Hda2 (Fig. 4A, lanes 5,6). Notably, antisense RNAs were detectable neither in $\Delta$ pho84 nor in $\Delta$ pho84 $\Delta$ hda2 strains. Since endogenous antisense RNAs are degraded by Rrp6, we also transformed the GAL- $N^{\circ} 1$ plasmid into a $\Delta$ pho84 $\Delta$ rrp 6 strain and checked for antisense RNA accumulation in cells grown in glucose versus galactose. In the absence of Rrp6, antisense RNAs were stabilized in strains cultivated in galactose but not glucose (Fig. 4A, lanes 3,4), demonstrating that antisense transcripts are made in galactose but are very unstable. In Drosophila, the exosome is directed to RNA poll II within transcription hot-spots (Andrulis et al. 2002). Thus, increased instability of antisense transcripts driven by the strong GAL promoter could be due to increased recruitment of the exosome. 
A
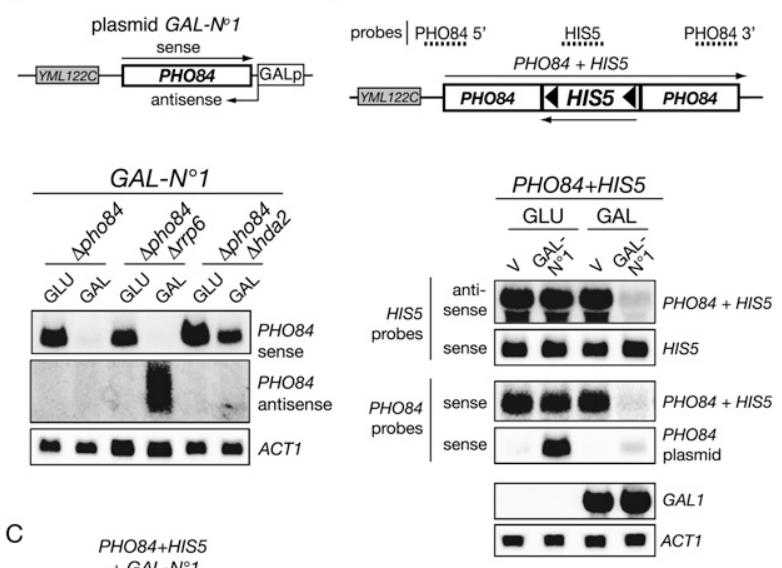

C

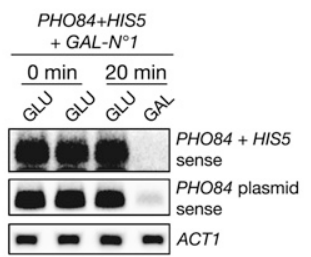

Figure 4. GAL-driven $P H O 84$ antisense RNAs silence endogenous PHO84 gene expression in trans. (A) PHO84 cis-silencing is recapitulated on plasmid. $\mathrm{PHO} 84$ sense and antisense RNA

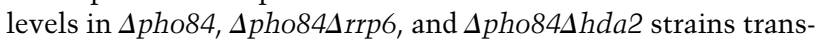
formed with a $\mathrm{PHO} 84$ plasmid in which antisense RNAs are driven by a galactose-inducible promoter $\left(G A L-N^{\circ} 1\right)$ as drawn at the top. Cells were exponentially cultivated $24 \mathrm{~h}$ in -LEU medium containing $2 \%$ glucose (GLU) or $2 \%$ galactose (GAL) and PHO84 sense and antisense RNAs produced from the plasmid were detected as in Figure 1B. (B) GAL-inducible antisense RNAs promote TGS in trans. (Top) Map of the PHO84 + HIS5 endogenous gene. The S. pombe HIS5 gene was inserted within PHO84 in reverse orientation and is flanked by TEF promoter and terminator sequences (black triangles). Arrows indicate the orientation of the sense transcripts expressed from this locus. Dotted lines correspond to the position of PHO84 and HIS5 probes used below. (Bottom) Northern analysis of RNA from the PHO84+HIS5 strain transformed with empty vector (V) or plasmid $G A L-N^{\circ} 1$. Transformants were exponentially grown for $24 \mathrm{~h}$ in -LEU media containing $2 \%$ glucose (GLU) or $2 \%$ galactose (GAL). (Top panels) PHO84 + HIS5 and HIS5 sense transcripts were detected with HIS5 antisense- and sense-specific probes. (Middle panels) PHO84 + HIS and PHO84 plasmid transcripts were also detected with a $\mathrm{PHO} 84$ sense-specific probe. GAL1 and ACT1 mRNAs were detected with random primed probes and served, respectively, as galactose induction and loading controls. $(C)$ TGS by GAL-induced PHO84 antisense RNAs is rapid. The PHO84 + HIS5 cells transformed with plasmid GAL$N^{\circ} 1$ were grown in -LEU medium containing $2 \%$ glucose. After $24 \mathrm{~h}$, cells were spun and resuspended in -LEU media containing either $2 \%$ glucose (GLU) or $2 \%$ galactose (GAL) and grown for an additional $20 \mathrm{~min}$.

Since the regulation of antisense RNA expression with the GAL promoter allows to control silencing in cis, we used this construct to test whether PHO84 cosuppression is mediated by trans-acting antisense RNAs. Plasmid GAL-N 1 was transformed into a strain containing a HIS5 cassette in the middle of PHO84 in reverse orientation such that endogenous antisense RNAs are prematurely terminated and silencing in cis is impaired (Camblong et al. 2007). While cells grown in glucose expressed both the endogenous and the plasmid PHO84 genes, distinguishable in size because of the HIS5 cassette, cells cultivated in galactose exhibited silencing of both PHO84 copies (Fig. 4B). Therefore, antisense RNAs produced from the plasmid can silence plasmid $\mathrm{PHO} 84$ gene expression in cis and endogenous PHO84 gene expression in trans. In addition, the silencing is very fast as 20 min of galactose induction was sufficient to repress endogenous PHO84 gene expression (Fig. 4C). Considering that $\mathrm{PHO} 84$ sense mRNA half-life is about $8 \mathrm{~min}$ (Wang et al. 2002), this last result supports the view that antisense RNA-mediated PHO84 gene cosuppression is very rapid and penetrant. Finally, the fact that the HIS5 cassette expressed a HIS5 sense RNA in both glucose and galactose conditions indicated that HIS5 transcription is not silenced (Fig. 4B). Thus, PHO84 cosuppression is mediated by trans-acting antisense RNAs, which have the ability to target and restrict silencing to a specific sequence; i.e., the $\mathrm{PHO} 84$ promoter.

\section{Cleavage of antisense RNA is sufficient to impair cis- and trans-mediated silencing}

In some experiments with the GAL-inducible antisense transcripts described above, the GAL promoter turned out to be leaky, resulting in partial silencing of the endogenous $\mathrm{PHO} 84$ gene even in glucose (data not shown; see below). To confirm the importance of antisense RNA in trans-silencing, we developed an alternate approach aimed at cleaving antisense transcripts rather than regulating their transcription. Based on Pho84 structure predictions, a 51-nucleotide hammerhead ribozyme (Rz) was inserted in frame in the middle of $\mathrm{PHO} 84$ ORF so that the Pho84 protein structure should not be dramatically disturbed (Fig. 5A). The Rz sequence was inserted in the reverse orientation to specifically induce self-cleavage of antisense RNA. To test the efficiency of the ribozyme, we performed an aging experiment with strains in which the endogenous $\mathrm{PHO} 84$ gene had been replaced by a $\mathrm{PHO} 84$ gene containing either the wild-type (PHO84Rz) or a mutant ribozyme (PHO84Rzm) harboring a single base change in its catalytic site that abolishes self-cleavage (Fig. 5B; Samarsky et al. 1999; Lacadie et al. 2006). As shown earlier, PHO84 expression was silenced in the progeny of 25-d-old wild-type cells (Fig. 5B, lanes $1,2)$. In contrast, the insertion of $\mathrm{Rz}$, but not $\mathrm{Rzm}$, led to reduced antisense RNA levels and maintenance of PHO84 sense expression in aged cells (Fig. 5B, lanes $3,4)$. Although Northern analyses failed to detect shortened $\mathrm{PHO} 84$ antisense transcripts, these results strongly support the view that loss of $\mathrm{PHO} 84$ silencing results from antisense RNA cleavage in presence of Rz.

To further confirm that PHO84 cosuppression also depends on antisense RNAs produced in trans, two new plasmids similar to $\mathrm{N}^{\circ} 1$ but containing the $\mathrm{Rz}$ or $\mathrm{Rzm}$ sequences were constructed ( $\mathrm{N}^{\circ} 1 \mathrm{Rz}$ and $\left.\mathrm{N}^{\circ} 1 \mathrm{Rzm}\right)$ and transformed into the $\Delta$ ter strain, which produces a long PHO84 read-through transcript distinguishable from 
A

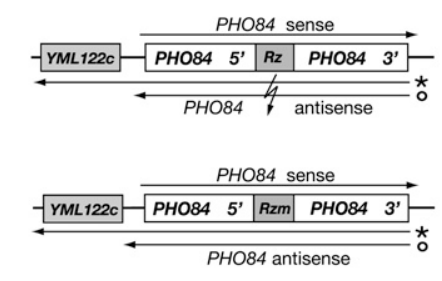

C

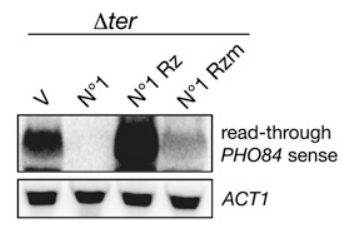

B

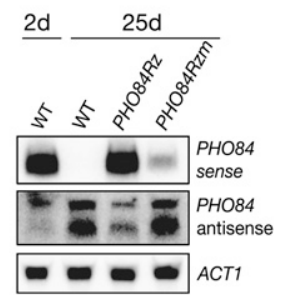

D

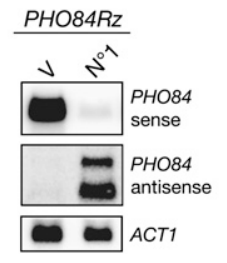

Figure 5. $P H O 84$ antisense RNA self-cleavage blocks silencing in cis and trans. (A) Map of the PHO84-ribozyme chimeric gene. A PHO84 gene containing a 51-mer wild-type (Rz) or mutant (Rzm) hammerhead ribozyme sequence was integrated in place of the endogenous PHO84 gene (strains PHO84Rz and PHO84Rzm) or inserted within the plasmid PHO84 $\mathrm{N}^{\circ} 1\left(\mathrm{~N}^{\circ} 1 \mathrm{Rz}\right.$ and $\left.\mathrm{N}^{\circ} 1 \mathrm{Rzm}\right)$. Arrows indicate $\mathrm{PHO} 84$ sense and antisense transcripts. (B) Cleavage of endogenous PHO84 antisense RNA blocks PHO84 silencing in aged cells. Northern analysis of PHO84 sense and antisense RNAs in the progeny 25-d-old wildtype, PHO84Rz, and PHO84Rzm strains and the progeny of 2-d-old wild-type cells. $(C)$ Cleavage of plasmid-encoded antisense RNA blocks silencing of endogenous PHO84. Ater cells (Fig. 3D) transformed with empty vector $(\mathrm{V})$, plasmid $\mathrm{N}^{\circ} 1\left(\mathrm{~N}^{\circ} 1\right)$ as such or containing wild-type $\left(\mathrm{N}^{\circ} 1 \mathrm{Rz}\right)$ or mutant ribozyme $\left(\mathrm{N}^{\circ} 1 \mathrm{Rzm}\right)$ were analyzed as in Figure $1 \mathrm{~B} .(D)$ Cleavage of endogenous $\mathrm{PHO} 84$ antisense RNAs does not affect silencing in trans. The $P H O 84 R z$ strain (see $A, B$ ) transformed with empty vector or plasmid $\mathrm{N}^{\circ} 1\left(\mathrm{~N}^{\circ} 1\right)$ was analyzed as in Figure 1B.

plasmid-derived PHO84 sense RNAs (Fig. 3D,E). While transformation of plasmids $\mathrm{N}^{\circ} 1$ and $\mathrm{N}^{\circ} 1$ Rzm triggered silencing of endogenous $\mathrm{PHO} 4$ transcripts, plasmid $\mathrm{N}^{\circ} 1$ $\mathrm{Rz}$ failed to do so (Fig. 5C). Thus, as concluded previously from the experiments using the GAL promoter, antisense RNAs can silence $\mathrm{PHO} 84$ gene transcription both in cis and in trans.

To address whether PHO84 cosuppression requires endogenous antisense RNAs, plasmid $\mathrm{N}^{\circ} 1$ was transformed into the strain containing the integrated PHO84-Rz gene (Fig. 5D). This transformation led to the silencing of $\mathrm{PHO} 84$ gene expression, indicating that antisense RNAs produced in trans from the plasmid are sufficient. This conclusion is consistent with the observation that silencing in trans is also not impaired when endogenous antisense transcripts are blocked by insertion of the HIS5 cassette (Fig. 4B).

\section{Set1 influences the silencing in trans by promoting} production of antisense RNAs

Recently, it was proposed that Ty1 antisense RNAs escaping cytoplasmic degradation act in trans to repress Ty1 sense RNA transcription through a still poorly defined

mechanism involving the Set1 histone methyltransferase (Berretta et al. 2008). Notably, Set1 dimethylates and trimethylates $\mathrm{H} 3 \mathrm{~K} 4$ in the middle of the PHO84 ORF (Shukla et al. 2006), raising the question of whether Set 1 may also participate in $\mathrm{PHO} 44$ cosuppression. To address this possibility, an empty vector and plasmid $\mathrm{N}^{\circ} 1$ were transformed into the $\Delta$ set 1 strain. In addition, these strains were complemented with an empty or SET1containing plasmid. Transformation of plasmid $\mathrm{N}^{\circ} 1$ failed to induce efficient silencing unless $\Delta$ set 1 was complemented, suggesting that Set1 is implicated in the mechanism of silencing in trans (Fig. 6A, lanes 5,6). Set1 contains two RNA Recognition Motifs (RRM1 and RRM2), which could be required to recognize antisense RNAs and induce silencing. To test this possibility, the $\Delta$ set 1 strain containing plasmid $\mathrm{N}^{\circ} 1$ was transformed with SET1 plasmids in which the RRM1 or RRM2 motifs were mutated (Tresaugues et al. 2006). These Set1 mutants were still able to restore silencing, indicating that the RNA recognition motifs of Set1 are not implicated (Fig. 6A, lanes 6-8).

Notably, PHO84 antisense RNA levels in the $\Delta$ set 1 strain were reduced in the noncomplemented condition as compared with the three complemented conditions (Fig. $6 \mathrm{~A}$; see below), suggesting that Set1 may influence silencing through the regulation of antisense RNA production. To address whether Set 1 acts upstream of or downstream from antisense RNAs in PHO84 silencing, wild-type and $\Delta$ set1 strains were transformed with an empty vector or plasmid GAL-N ${ }^{\circ} 1$ (Fig. 6B). Induction of antisense RNAs from the heterologous galactose-inducible promoter led to sense RNA silencing even in the absence of Set1 (Fig. 6B, cf. lanes 2,4 and 6,8). This observation supports the view that Set 1 acts upstream of PHO84 antisense RNAs and triggers silencing primarily by stimulating the production of trans-acting antisense RNAs. Note that the decreased PHO84 sense expression in the wild-type strain containing GAL-N ${ }^{\circ} 1$ grown in glucose (Fig. $6 \mathrm{~B}$, lane 3 ) is due to promoter leak and production of sufficient antisense RNA to trigger partial silencing.

A role for Set1 in antisense production was also observed when comparing PHO84 transcript levels in wild type and $\Delta$ set 1 cells grown on plates for $2 \mathrm{~d}$. In these conditions, loss of Set1 results in reduced antisense and slightly increased sense RNA levels, indicating that Set1 contributes to silencing in cis (Supplemental Fig. 4). The absence of Set1, however, did not impact on PHO84 mRNA levels in aged cells, suggesting that Set1 is required at early stages and that additional chromatinmodifying activities may take over to silence $\mathrm{PHO} 84$ in aging cells (Katan-Khaykovich and Struhl 2005). The same phenotypes were observed in the H3K4A mutant. These data together are consistent with the view that Set1 H3K4 methylation participates in trans-silencing by promoting antisense RNA production.

\section{Antisense RNA levels and homology requirements for target gene silencing}

The observation that only the longest $\mathrm{PHO} 84$ constructs $\mathrm{N}^{\circ} 1$ and $\mathrm{N}^{\circ} 2$ were able to induce silencing in trans (Fig. 
A

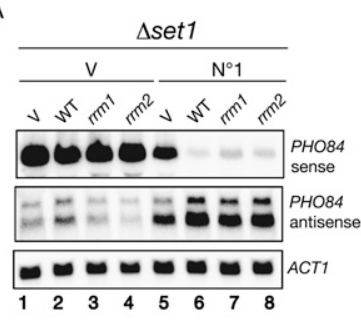

C

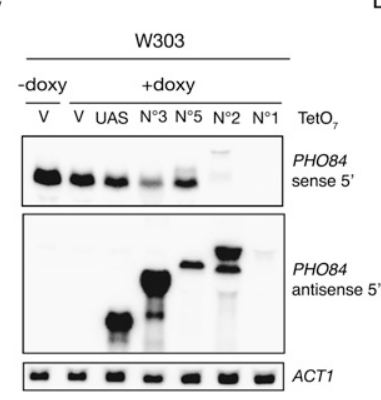

Figure 6. Antisense RNAs are stimulated by Set1 and require both $5^{\prime}$ and $3^{\prime}$ sequences to mediate silencing. (A) SET1 is implicated in $\mathrm{PHO} 84$ gene cosuppression. $\Delta$ set 1 cells containing an empty YCpLac33 vector (V), or complemented with plasmids encoding wild-type SET1 or the rrm1 and rrm2 mutant forms, were transformed with a YCpLac111 vector $(\mathrm{V})$ or the PHO84 plasmid $\mathrm{N}^{\circ} 1$ and analyzed as in Figure 1B. (B) PHO84 antisense RNAs driven by a GAL promoter bypass the requirement for Set 1 to trigger PHO84 cosuppression. Wild-type and $\Delta$ set 1 cells transformed with empty vector or plasmid GAL- ${ }^{\circ} 1$ were grown for $24 \mathrm{~h}$ in -LEU medium containing $2 \%$ glucose (GLU) or $2 \%$ galactose (GAL). PHO84 sense and antisense RNA levels were measured as in Figure 1B. (C) Efficient silencing requires long antisense RNAs containing both $\mathrm{PHO} 843^{\prime}$ end and UAS sequences. The W303 wild-type strain was transformed with the $\mathrm{TetO}_{7}$ pCM252 vector alone $(\mathrm{V})$ or containing the $\mathrm{PHO} 44$ portions UAS, N`3, N5, N², $\mathrm{N}^{\circ} 1$ (Fig. 3A). Cells were exponentially grown for $16 \mathrm{~h}$ in - TRP media without $(-)$ or with $(+)$ doxycycline $(20 \mu \mathrm{g} / \mathrm{mL})$ to induce antisense RNAs. PHO84 sense and antisense RNAs were detected with single-stranded probes specific for PHO84 5' end (Fig. 3A). ACT1 mRNA served as loading control. (D) Diagram of the chromosomal pho84::URA3 gene. The PHO84 ORF (codons 1 to stop) was replaced by the $K$. lactis $U R A 3$ ORF (codons 1 to stop), so that URA3 transcription is driven by the PHO84 UAS promoter region. Total RNA extracted from the $\Delta p h o 84:: U R A 3$ strain containing an empty vector $(\mathrm{V})$ or plasmid $\mathrm{N}^{\circ} 1$ was probed with probes specific for URA3 sense and PHO84 antisense transcripts, and ACT1 for loading control.

3B) suggested that antisense transcripts had to be long and contain sequences corresponding to the UAS (Fig. 3C). To confirm these results and address whether shorter antisense transcripts would be able to induce silencing if overexpressed, the PHO84 portions $\mathrm{N}^{\circ} 1, \mathrm{~N}^{\circ} 2, \mathrm{~N}^{\circ} 3$, and $\mathrm{N}^{\circ} 5$, as well as the upstream region corresponding to PHO84 UAS (positions -1 to -725 ), were cloned inverted behind a $\mathrm{TetO}_{7}$ promoter (Fig. 3A). Although large amounts of shorter antisense RNAs were produced from the UAS, $\mathrm{N}^{\circ} 3$, and $\mathrm{N}^{\circ} 5$ constructs, they induced no or only modest $\mathrm{PHO} 84$ silencing in case of $\mathrm{N}^{\circ} 3$. In contrast, very potent $\mathrm{PHO} 84$ gene repression was observed in the presence of the Tet- $\mathrm{N}^{\circ} 1$ and Tet- $\mathrm{N}^{\circ} 2$ constructs (Fig. $6 \mathrm{C}$ ), confirming that full-length antisense RNAs containing both $\mathrm{PHO} 84 \mathrm{3}^{\prime}$ end and UAS complementary sequences are necessary to mediate $\mathrm{PHO} 84$ cosuppression. Note that although very efficient, antisense RNAs from Tet$\mathrm{N}^{\circ} 1$, as from GAL-N ${ }^{\circ} 1$ (Fig. 4A), are unstable and hard to detect. Moreover Tet- $\mathrm{N}^{\circ} 1$ and Tet- $\mathrm{N}^{\circ} 2$ were able to induce silencing even in the absence of doxycycline (Supplemental Fig. 3; data not shown), indicating that very low amounts of these long antisense RNAs, resulting from the leaky $\mathrm{TetO}_{7}$ promoter, are sufficient to induce silencing.

As a complementary approach to define the minimal homology region between these long antisense transcripts and the target gene required for silencing, strain $\Delta$ pho84::URA3 was constructed in which the PHO84 coding region (from codon 1 to stop) was replaced by the Kluyveromyces lactis URA3 coding sequence. In this strain, the URA3 gene is driven by $P H O 84$ UAS promoter and followed by PHO84 3'UTR sequences (Fig. 6D). Interestingly, transformation of plasmid $\mathrm{N}^{\circ} 1$ induced a reduction in URA3 mRNA levels, indicating that a homology restricted to the PHO84 UAS promoter between the trans-acting antisense RNAs and the target gene is sufficient to trigger silencing, consistent with an effect on transcription initiation (Fig. 2A,B).

\section{Antisense production does not necessarily promote silencing in trans of other genes}

An important question is whether other antisense RNAproducing genes can mediate transcriptional cosuppression. Candidate genes (VTC3, YJR129c, and GYP5) were identified based on recently published tiling array analyses comparing sense and antisense RNAs in wild-type versus $\Delta$ rrp6 strains (Xu et al. 2009). Gene-specific RTqPCR analyses confirmed that stabilization of $\mathrm{PHO} 84$, VTC3, YJR129c, and GYP5 antisense RNAs leads to sense RNA repression (Fig. 7A), suggesting that antisense RNAmediated TGS in cis is not a rare phenomenon. In addition, these analyses revealed that several pathways might exist as PHO84 and VTC3 silencing, but not GYP5 and YJR129 silencing, depends on Hda2 (Fig. 7A).

Next, to address whether these antisense RNAs may trigger cosuppression in trans, a wild-type strain was transformed with an empty vector, with centromeric plasmids containing each gene expressed from its own promoter, or with centromeric plasmids with each gene cloned upstream of a GAL promoter, allowing overexpression of antisense transcripts in galactose. The levels of sense transcripts expressed in the transformed strains were determined by RT-qPCR using primers specific for each gene (Fig. 7B). None of the strains transformed with the VTC3, YJR129c, and GYP5 plasmids showed a decrease in the corresponding sense RNA levels compared with those detected in presence of the empty vector. Thus trans-silencing is not a general feature of antisenseproducing genes.

As mentioned earlier, expression of the PHO84 + HIS5 transcript can be silenced in trans by galactose-induced 
A
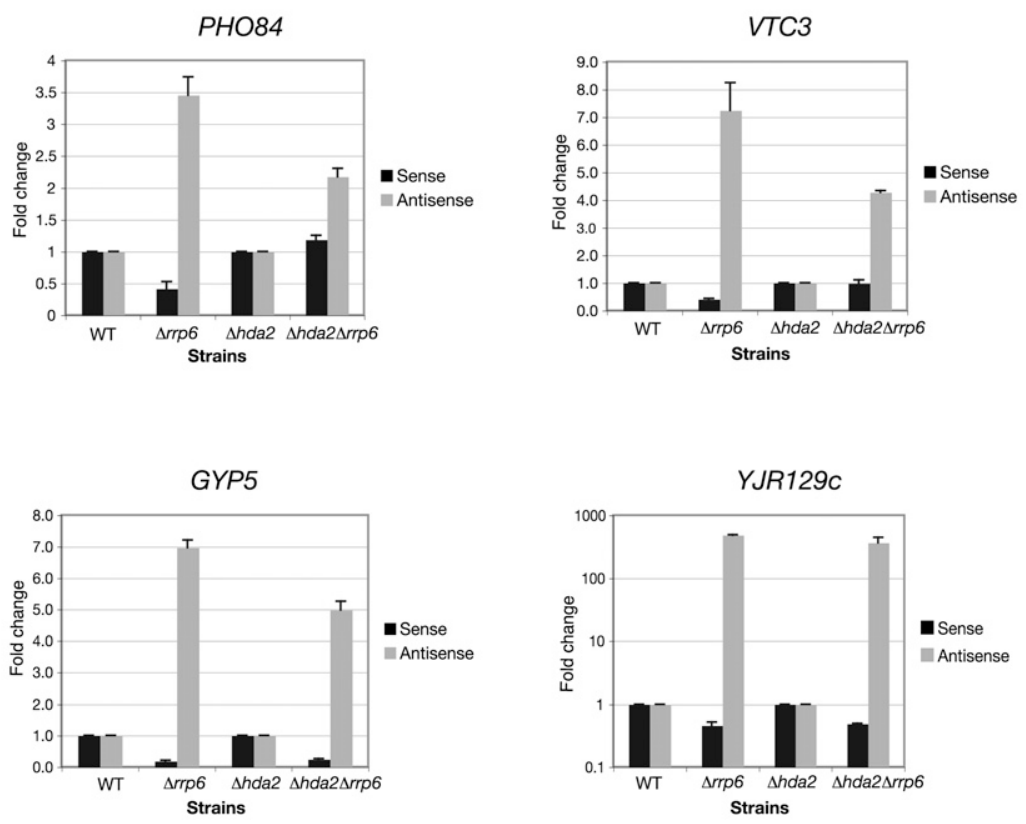

B

C
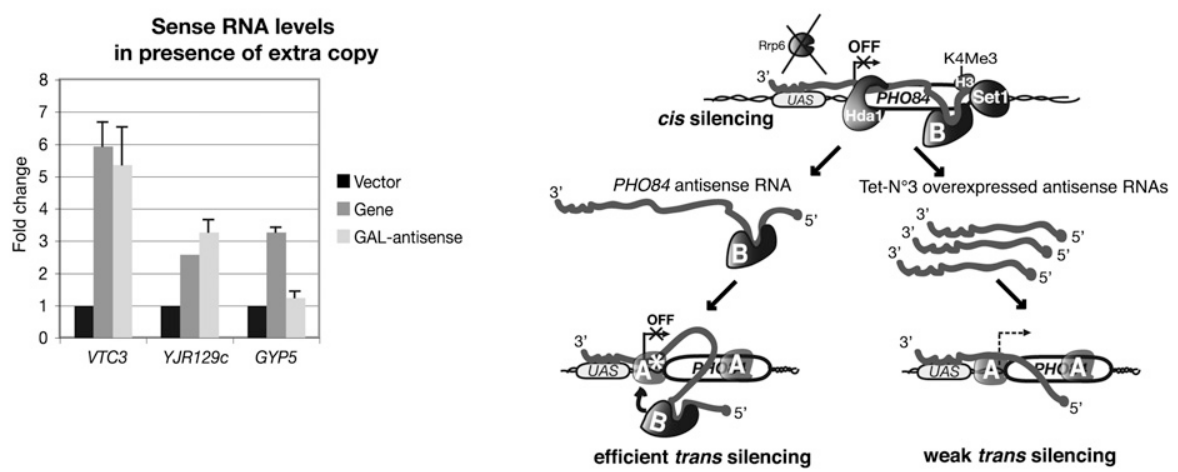

Figure 7. Analysis of candidate genes regulated by antisense transcripts like PHO84. (A) RT-qPCR analysis of PHO84, VTC3, YJR129c, and GYP5 sense and antisense RNA levels in wild-type, $\Delta$ rrp6, $\Delta$ hda2, and $\Delta$ hda2 $\Delta$ rrp 6 strains exponentially grown in SC medium $+2 \%$ glucose. Values are represented as fold change of sense or antisense RNA levels in $\Delta$ rrp6 versus wild type and in $\Delta$ hda2 $\Delta$ rrp6 versus $\Delta$ hda2. (B) VTC3, YJR129c, and GYP5 antisense RNAs do not trigger silencing in trans. The W303 wild-type strain was transformed with empty vector $(\mathrm{V})$, plasmids containing the three candidate genes with their own regulatory sequences (gene) or plasmids containing the three candidate genes behind a GAL promoter such that antisense RNAs are induced in galactose (GAL antisense). Cells were exponentially grown in $-\mathrm{LEU}+2 \%$ glucose (vector and gene) or in $-\mathrm{LEU}+2 \%$ galactose (vector and GAL antisense). Total RNA was subjected to RT-qPCR analyses with gene-specific probes. Values are expressed as fold change versus the vector control in the two different conditions. $(C)$ Model shows antisense RNAs mediate cis and trans transcriptional gene silencing. Set1 H3K4 methylation promotes antisense RNA production. In cis, antisense RNAs escaping degradation by the nuclear exosome can trigger transcriptional gene silencing in an Hda1/2/3-dependent (PHO84 and VTC3) or Hdal/2/3-independent (GYP5 and YJR129C) way. In trans, PHO84 antisense RNAs silence the homologous target sequence at the transcriptional level due to a homology region with the UAS promoter sequence. We propose that this requires an unidentified silencing factor coating the PHO84 gene (named A). Importantly, while high amounts of short trans-acting antisense RNAs (Tet- $\mathrm{N}^{\circ} 3$ ) are weak in inducing silencing by A, small amounts of long antisense RNAs originating from the $3^{\prime}$ end of $\mathrm{PHO} 84$ gene are very effective (plasmid $\mathrm{N}^{\circ} 1$ ). We speculate that a silencing factor (named $\mathrm{B}$ ) might be recruited by these long RNAs and would interact with the prebound repressor A enhancing its silencing activity $\left(\mathrm{A}^{\star}\right)$. The same hypothesis might explain why other antisense RNAs are ineffective in trans (VTC3, GYP5, and YJR129C).

PHO84 antisense RNAs (Fig. 4B). This repression, however, does not affect the expression of the S. pombe HIS5 gene inserted in the reverse orientation within PHO84. To address whether the context of the PHO84 gene may favor trans-silencing, we tested whether overexpression of HIS5 antisense transcripts from a $\mathrm{TetO}_{7}$ promoter could silence the HIS5 gene located within the PHO84 + HIS5. Due to the leakiness of the promoter, HIS5 
antisense transcripts were detected already in the absence of induction but strongly increased following overnight treatment with doxycycline. Interestingly, antisense RNA accumulation correlated with some decrease in HIS5 sense transcripts encoded by the PHO84-HIS5 chimeric gene (Supplemental Fig. 5). These observations suggest that, while antisense-mediated trans-silencing is not a general feature (Fig. 7B), antisense RNAs can induce silencing in trans if they target a sequence in the context of the PHO84 gene. However, as observed with construct $\mathrm{N}^{\circ} 3$ (Fig. 6C), silencing was not very potent despite the accumulation of large amounts of antisense RNA.

\section{Discussion}

Recently, high-resolution transcriptome analysis in budding yeast (Neil et al. 2009; Xu et al. 2009) and in mammals (Affymetrix/Cold Spring Harbor Laboratory ENCODE Transcriptome Project 2009) reported the existence of a growing family of long noncoding RNAs. Among these, several have been described to regulate transcription of protein coding genes in cis (Martens et al. 2004; Hongay et al. 2006; Camblong et al. 2007; Uhler et al. 2007; Houseley et al. 2008). In the present study, we show that $\mathrm{PHO} 84$ antisense RNAs induce transcriptional cosuppression in trans, highlighting that homologydependent gene silencing is not the exclusivity of organisms containing the RNAi machinery.

\section{Antisense RNAs trigger PHO84 TGS in cis and in trans}

We previously proposed that, in S. cerevisiae, antisense RNAs accumulated in cis target TGS through histone deacetylation (Camblong et al. 2007). In the present study, we show that induction of antisense RNAs from a plasmid can bypass the requirement of natural $\mathrm{PHO} 84$ antisense RNAs and direct endogenous $\mathrm{PHO} 84$ gene silencing in trans (Fig. 4B) prior to cytoplasmic export (Supplemental Fig. 6). Consistently, self-cleaved antisense RNAs were inefficient in inducing silencing not only in cis but also in trans (Fig. 5B,C). Moreover, transacting antisense RNAs are very potent (Fig. 4C) and act rapidly at the transcription initiation level, completely blocking TBP recruitment to the PHO84 promoter (Fig. 2B). However, the effects of cis and trans-acting antisense RNAs differ by the requirement of the $\mathrm{Hdal} / 2 / 3$ histone deacetylase complex. While $\mathrm{Hdal} / 2 / 3$ dependency reflects the cis mechanism (Fig. 4A; Camblong et al. 2007), trans-acting antisense RNAs induce silencing independently of this HDAC (Fig. 2C; Supplemental Fig. 3). Thus RNA-mediated PHO84 TGS relies on at least two alternative pathways. Together, these findings provide the first evidence in $S$. cerevisiae that antisense RNAs can act in trans to silence transcription of a protein coding gene. Moreover, the data show that the same gene can be silenced by antisense RNAs acting in cis or in trans. These observations strengthen the view that antisense RNAs are central players in directing TGS in budding yeast.
A role for Set1 in gene regulation by promoting antisense production

Among all the mutants disrupted for chromatin-related functions that we tested so far (Supplemental Table 3), $\Delta$ set 1 was the only one to show a defect in PHO84 transsilencing. Our data indicate that the Set1 H3K4 methyltransferase participates in cosuppression by promoting PHO84 antisense RNA production (Fig. 6A,B). Remarkably, Set1 activity has also been linked to heterochromatin formation at the HM (Katan-Khaykovich and Struhl 2005) and rDNA (Briggs et al. 2001) loci. In addition, noncoding RNAs subjected to degradation by the nuclear exosome have been identified recently within rDNA silenced regions (Houseley et al. 2007; Vasiljeva et al. 2008). Since H3K4 trimethylation correlates with active chromatin states (Noma and Grewal 2002), the silencing defects observed in the absence of Set 1 could reflect its role in facilitating the production of noncoding RNAs, which in turn may target silencing factors to corresponding DNA regions. An earlier study showed that PHO84 and GAL1-10, two genes that were shown recently to produce and to be regulated negatively by antisense transcripts (Camblong et al. 2007; Houseley et al. 2008; $\mathrm{Xu}$ et al. 2009), become derepressed in the absence of Set 1 (Carvin and Kladde 2004). Notably, a recent genome wide study showed that in S. cerevisiae, H3K4 methylation is not only promoter-associated but also present within ORFs and at the $3^{\prime}$ end of a number of genes (Kirmizis et al. 2007). Moreover, a number of these genes become derepressed in the absence of Set 1 and express antisense transcripts (F Holstege and V Géli, pers. comm.). These observations together indicate that Set 1 is a key player in regulating antisense RNA-mediated TGS. Whether H3K4 methylation by Set1 during transcription influences RNA PolII processivity, increases antisense RNA stability, and/or facilitates the recruitment of silencing factors are important questions for the future.

\section{Antisense RNA features required for TGS}

To address the generality of antisense-induced transsilencing, we selected, based on recently published genome-wide analyses (Xu et al. 2009), three candidate genes exhibiting antisense RNA accumulation and sense RNA repression in the absence of Rrp6 (Fig. 7A). Despite a mode of regulation similar to $\mathrm{PHO} 84$, none of these genes was able to induce cosuppression, whether expressed from a plasmid with their own promoter or with a GAL promoter driving antisense transcription (Fig. 7B). Thus, besides antisense production, additional, yet unidentified, $\mathrm{PHO} 84$-specific features are required for cosuppression to take place.

Our studies show that antisense-induced silencing in trans occurs at the transcriptional level (Fig. 2). Although very modest trans-silencing can be observed when truncated antisense RNAs containing UAS sequences are overexpressed, potent cosuppression is achieved only when long antisense RNAs, containing sequences complementary to both $\mathrm{PHO} 84$ UAS and $3^{\prime}$ end, are produced (Fig. 6C). These long antisense transcripts are effective 
even when present in very low amounts (Figs. 4B, 6C; Supplemental Fig. 3), suggesting that these RNAs are merely required to initiate rather than to maintain the silenced state. Interestingly, the long $\mathrm{PHO} 84$ antisense transcripts are able to promote transcriptional silencing of the pho84::URA3 target gene, whose homology with plasmid encoded antisense RNAs is restricted to the PHO84 UAS region (Fig. 6D). One possible scenario could be that factors implicated in TGS are recruited to the antisense RNA at early phases of transcription to subsequently facilitate promoter homology-driven silencing events (see the model in Fig. 7C). Finally, we show that a S. pombe HIS5 gene embedded within the PHO84 gene is down-regulated, albeit not very efficiently, when HIS5 antisense transcripts are overexpressed in trans (Supplemental Fig. 5). These observations suggest that the PHO84 gene may provide a chromatin environment prone to silencing by trans-acting antisense RNAs.

\section{Analogies with RNA-mediated TGS and $X$-chromosome inactivation (XCI) in metazoa}

Similar to antisense-induced PHO84 promoter transsilencing, ectopic expression of antisense RNAs in mammalian cells triggers TGS at targeted promoters, provided these are transcribed in the sense orientation (Weinberg et al. 2006; Han et al. 2007). Although likely, a role in promoter silencing has not yet been demonstrated for naturally occurring mammalian antisense transcripts. In contrast, HOTAIR, and Xist are two natural long noncoding RNAs involved in trans-repression of the mammalian HOXD locus and XCI, respectively (Rinn et al. 2007; Erwin and Lee 2008). Our finding that PHO84 trans-silencing requires a 2.5 -kb-long sequence containing the complete PHO84 ORF and the upstream UAS (Fig. $3 \mathrm{~A}, \mathrm{~B})$ raises parallels with $\mathrm{XCI}$ and the possibility that the PHO84 ectopic and endogenous copies physically interact. Indeed, in XCI, expression of trans-acting Tsix and Xite noncoding RNAs from, respectively, 3.7- and 5.6-kb-long sequences promotes $X$ chromosome pairing and initiates Xist-dependent inactivation of one of the two copies (Xu et al. 2006).

How closely PHO84 cosuppression relates to these phenomena, how extra copies are sensed and whether gene repression results from transient pairing of homologous sequences are important open questions. Future experiments aim at identifying the factors implicated in antisense-mediated trans-silencing, at defining the PHO84 gene features enabling antisense RNAs to trigger silencing in trans, as well as understanding the physiological relevance of this regulation. The genetic dissection of this pathway in the budding yeast may provide important new insights into RNAi-independent mechanisms in higher eukaryotes.

\section{Materials and methods}

\section{Plasmid constructions}

PHO84 sequences $\mathrm{N}^{\circ} 1-\mathrm{N}^{\circ} 6$ were cloned as SalI-BamHI PCR fragments (see Supplemental Table 2 for primers) into
YCpLac111 and correspond, respectively, to $\mathrm{PHO} 84$ positions -725 to $+165\left(\mathrm{~N}^{\circ} 1, \mathrm{pFS} 3178\right),-725$ to stop $\left(\mathrm{N}^{\circ} 2, \mathrm{pFS} 3181\right),-725$ to 770 (N³, pFS3182), -200 to +165 (N॰4, pFS3183), -200 to stop ( ${ }^{\circ} 5$, pFS3184), and -200 to 770 ( $\mathrm{N}^{\circ} 6$, pFS3185). Plasmid GALYCpLac111 (pFS1932) was obtained by transferring the GAL1 UAS promoter region together with a multiple cloning site as an EcoRI-HindIII fragment from the high-copy galactose-inducible YEp-GAL vector (Lee et al. 1996) into YCpLac111. Construct GAL-N ${ }^{\circ} 1$ (pFS3247) was obtained by subcloning the SalI-BamHI PHO84 fragment $\mathrm{N}^{\circ} 1$ in the inverse orientation behind the GAL promoter of plasmid GAL-YCpLac111 cut with SalI and BamHI. pCM252-Nº1 (pFS3132), pCM252-N² (pFS3133), pCM252-ํ3 (pFS3478), and pCM252- $\mathrm{N}^{\circ} 5$ (pFS3481) were generated by inserting the $\mathrm{PHO} 84$ sequence $\mathrm{N}^{\circ} 1-\mathrm{N}^{\circ} 3$ and 5 in the reverse orientation behind the $\mathrm{TetO}_{7}$ promoter of vector pCM252 as BamHIStuI PCR fragments. pCM252-UAS (pFS3211) was obtained by cloning the region upstream of $\mathrm{PHO} 84$ (position -1 to -725 ) as a BamHI-StuI fragment behind the $\mathrm{TetO}_{7}$ promoter such that deoxycyline induces YML122c antisense RNA. To express $S$. pombe HIS5 antisense transcripts, a BamH1-StuI PCR fragment containing the coding and terminator but not the promoter sequences was generated using pUG27 (Gueldener et al. 2002) as template and cloned into pCM252 to obtain pFS3482. VTC3, YJR129c, and GYP5 were cloned as BamH1 PCR fragments into YCpLac111 to obtain pFS3465, pFS3466, and pFS3469; the same genes were cloned as $\mathrm{BamH1}$ fragments in reverse orientation behind the GAL promoter of YCpLac111-GAL (Stutz laboratory) to obtain pFS3462, pFS3463, and pFS3468.

The PHO84Rz and PHO84Rzm chimeric genes, containing a wild-type and a mutant 51-bp hammerhead ribozyme sequence, respectively, were obtained using a two-step PCR strategy and initially cloned into the integrating vector pRS406 cut with XhoI and SacI. Briefly a 5' fragment was generated with a 5' SalI primer (OFS1249) and a Rz or Rzm reverse primer (OFS1248 or OFS1299); a $3^{\prime}$ fragment was generated with a $\mathrm{Rz}$ or Rzm forward primers (OFS1247 or OFS1298) and the 3' SacI primer (OFS1250). The 5'and 3' PCR fragments were mixed and reamplified with OFS1249 and OFS1250 external primers to generate the full chimeric PHO84Rz and PHO84Rzm genes followed by insertion as a SalI-SacI fragment into pRS406 cut with XhoI + SacI to generate pFS3154 and pFS3231. The ribozyme containing genes were transferred as SacI-PvuII fragments from pRS406 into YCpLac111 cut with SacI + SmaI to generate pFS3218 and pFS3348. To insert PHO84 at other genomic locations, PHO84 was first cloned as a SalI PCR fragment next to the HIS5 marker in pUG27 (Gueldener et al. 2002) in either the forward or the reverse orientation to generate, respectively, pUG27-PHO84 for (pFS3328) and pUG27-PHO84 rev (pFS3329).

\section{Yeast strain constructions}

All yeast strains used in this study are described in Supplemental Tables 1 and 3. Gene deletions in W303 background were generated either by PCR amplification of the deleted locus in BY4741 (Euroscarf) with -500 and +500 primers and transformation into W303 or by PCR amplification of deletion cassettes as described (Longtine et al. 1998). The W303 strain containing a PHO84 + HIS5 gene (FSY3332) was constructed as described previously (Camblong et al. 2007). Strain PHO84Ater (FSY3657) was obtained by deleting $\mathrm{PHO} 84$ terminator sequences (position +50 to +170 ) through insertion of a LoxP-HIS5-LoxP cassette followed by excision of HIS5 by expression of Cre recombinase (Gueldener et al. 2002). The $\mathrm{Rz}$ and $\mathrm{Rzm}$ strains (FSY3346 and FSY3568) were obtained using a pop-in/pop-out gene replacement strategy. Briefly, the pRS406PHO84Rz and pRS406PHO84Rzm integrative plasmids (pFS3154 and pFS3231) 
were linearized with AvaI and transformed into W303. URA ${ }^{+}$ colonies were streaked on 5-FOA to select for loss of one of the two PHO84 gene copies. Retention of the ribozyme-containing gene was identified by PCR. The insertion of a PHO84 gene copy instead of LYS2, YML083, or GUD1 was obtained by PCR amplification of pFS3329 (for LYS2) and pFS3328 (for YMLO83 and GUD1) to generate PHO84-HIS5 fragments with sequences complementary to the target genes. W303 and $\Delta$ pho84 strains transformed with the PCR products were selected on -HIS medium and gene replacement at the target sites verified by PCR. The pho84-URA3 strain was obtained by replacement of the endogenous PHO84 coding region (codon 1 to stop) by the $K$. lactis URA3 coding region through targeted homologous recombination of a URA3 PCR fragment amplified from pUG72 (Gueldener et al. 2002), followed by selection of transformants on -URA plates.

\section{Media and culture conditions}

Yeast strains transformed with plasmids were grown for $3 \mathrm{~d}$ on plates before liquid culture for $24 \mathrm{~h}$ under exponential conditions (OD600 $<0.8$ ) in drop-out minimum medium. The wild-type, $\mathrm{Rz}$, and Rzm strains (Fig. 5B) were grown on YEPD plates at $25^{\circ} \mathrm{C}$ for $3 \mathrm{~d}$ and kept for 2 or $25 \mathrm{~d}$ at $4^{\circ} \mathrm{C}$ followed by cultivation in synthetic complete (SC) minimum medium for $24 \mathrm{~h}$ under exponential conditions.

\section{RNA extraction and analysis}

Total RNA was extracted with the hot phenol procedure and analyzed by Northern blotting (Camblong et al. 2007) or RT-qPCR (Xu et al. 2009). For Northern blots, all probes were SP6 or T7 (GAL1) riboprobes, except for ACT1, which was a random primed labeled probe. Quantifications were performed with a PhosphorImager. For RT-qPCR gene-specific primers were used for the RT reaction. All primers are described in Supplemental Table 2.

\section{ChIP}

ChIPs were performed essentially as described (Camblong et al. 2007). Yeast strains were grown to $\mathrm{OD}_{600}=1$ in - LEU medium for $15 \mathrm{~min}$ at $25^{\circ} \mathrm{C}$ and cross-linked by the addition of formaldehyde to a final concentration of $1.2 \%$. Cross-linked and sonicated chromatin extracts from $10^{8}$ cells were immunoprecipitated overnight in the presence of $50 \mu \mathrm{L}$ of $50 \%$ protein G Sepharose (Amersham Pharmacia) with antibodies against the C-terminal domain of the RNA Pol II (Abcam 8WG16) or the TBP (gift from M. Collart). All immunoprecipitations were performed in triplicate with different chromatin extracts. Immunoprecipitated DNA was quantified by real-time PCR using specific primer pairs (Camblong et al. 2007) and expressed as the fold increase over a nontranscribed intergenic region as in (Zenklusen et al. 2002). Error bars correspond to standard deviations.

\section{Acknowledgments}

We thank M. Collart for antibodies against TBP, A. Morillon for strains, and V. Géli for plasmids. We are indebted to S. Dersi and C. Fickentscher for technical assistance. We are grateful to B. Daignan-Fornier, A. Morillon, M.P. Pelli-Gulli, B. Pinson, N. Proudfoot, M. Strubin, and members of the laboratory for discussion and critical reading of the manuscript, and thank F. Holstege, V. Géli, and C. Dargemont for communication of unpublished data. This work was supported by a Roche Research Foundation fellowship to J.C., a SystemsX fellowship to E.G., the Swiss National Science Foundation (grant no. 116541) to F.S., the NCCR "Frontiers in Genetics," and the Canton of Geneva.

\section{References}

Affymetrix/Cold Spring Harbor Laboratory ENCODE Transcriptome Project. 2009. Post-transcriptional processing generates a diversity of 5 '-modified long and short RNAs. Nature 457: 1028-1032.

Andrulis ED, Werner J, Nazarian A, Erdjument-Bromage H, Tempst P, Lis JT. 2002. The RNA processing exosome is linked to elongating RNA polymerase II in Drosophila. Nature 420: 837-841.

Aravind L, Watanabe H, Lipman DJ, Koonin EV. 2000. Lineagespecific loss and divergence of functionally linked genes in eukaryotes. Proc Natl Acad Sci 97: 11319-11324.

Berretta J, Pinskaya M, Morillon A. 2008. A cryptic unstable transcript mediates transcriptional trans-silencing of the Tyl retrotransposon in S. cerevisiae. Genes \& Dev 22: 615-626.

Briggs SD, Bryk M, Strahl BD, Cheung WL, Davie JK, Dent SY, Winston F, Allis CD. 2001. Histone H3 lysine 4 methylation is mediated by Set 1 and required for cell growth and rDNA silencing in Saccharomyces cerevisiae. Genes \& Dev 15: 3286-3295.

Buhler M, Moazed D. 2007. Transcription and RNAi in heterochromatic gene silencing. Nat Struct Mol Biol 14: 1041-1048.

Buhler M, Verdel A, Moazed D. 2006. Tethering RITS to a nascent transcript initiates RNAi- and heterochromatindependent gene silencing. Cell 125: 873-886.

Camblong J, Iglesias N, Fickentscher C, Dieppois G, Stutz F. 2007. Antisense RNA stabilization induces transcriptional gene silencing via histone deacetylation in S. cerevisiae. Cell 131: 706-717.

Carvin CD, Kladde MP. 2004. Effectors of lysine 4 methylation of histone $\mathrm{H} 3$ in Saccharomyces cerevisiae are negative regulators of PHO5 and GAL1-10. J Biol Chem 279: 3305733062.

Erwin JA, Lee JT. 2008. New twists in X-chromosome inactivation. Curr Opin Cell Biol 20: 349-355.

Girard A, Hannon GJ. 2008. Conserved themes in small-RNAmediated transposon control. Trends Cell Biol 18: 136-148.

Gueldener U, Heinisch J, Koehler GJ, Voss D, Hegemann JH. 2002. A second set of loxP marker cassettes for Cre-mediated multiple gene knockouts in budding yeast. Nucleic Acids Res 30: $\mathrm{e} 23$.

Han J, Kim D, Morris KV. 2007. Promoter-associated RNA is required for RNA-directed transcriptional gene silencing in human cells. Proc Natl Acad Sci 104: 12422-12427.

Hongay CF, Grisafi PL, Galitski T, Fink GR. 2006. Antisense transcription controls cell fate in Saccharomyces cerevisiae. Cell 127: 735-745.

Houseley J, Kotovic K, El Hage A, Tollervey D. 2007. Trf4 targets ncRNAs from telomeric and rDNA spacer regions and functions in rDNA copy number control. EMBO $I$ 26: 4996-5006.

Houseley J, Rubbi L, Grunstein M, Tollervey D, Vogelauer M. 2008. A ncRNA modulates histone modification and mRNA induction in the yeast GAL gene cluster. Mol Cell 32: 685695.

Iida T, Nakayama J, Moazed D. 2008. siRNA-mediated heterochromatin establishment requires HP1 and is associated with antisense transcription. Mol Cell 31: 178-189.

Jorgensen RA. 1995. Cosuppression, flower color patterns, and metastable gene expression states. Science 268: 686-691.

Katan-Khaykovich Y, Struhl K. 2005. Heterochromatin formation involves changes in histone modifications over multiple cell generations. EMBO J 24: 2138-2149.

Kirmizis A, Santos-Rosa H, Penkett CI, Singer MA, Vermeulen M, Mann M, Bahler J, Green RD, Kouzarides T. 2007. 
Arginine methylation at histone H3R2 controls deposition of H3K4 trimethylation. Nature 449: 928-932.

Lacadie SA, Tardiff DF, Kadener S, Rosbash M. 2006. In vivo commitment to yeast cotranscriptional splicing is sensitive to transcription elongation mutants. Genes \& Dev 20: 20552066.

Lee MS, Henry M, Silver PA. 1996. A protein that shuttles between the nucleus and the cytoplasm is an important mediator of RNA export. Genes \& Dev 10: 1233-1246.

Longtine MS, McKenzie A III, Demarini DI, Shah NG, Wach A, Brachat A, Philippsen P, Pringle JR. 1998. Additional modules for versatile and economical PCR-based gene deletion and modification in Saccharomyces cerevisiae. Yeast 14: 953961.

Martens JA, Laprade L, Winston F. 2004. Intergenic transcription is required to repress the Saccharomyces cerevisiae SER3 gene. Nature 429: 571-574.

Matzke AJ, Matzke MA. 1995a. Trans-inactivation of homologous sequences in Nicotiana tabacum. Curr Top Microbiol Immunol 197: 1-14.

Matzke MA, Matzke AJ. 1995b. Homology-dependent gene silencing in transgenic plants: What does it really tell us? Trends Genet 11: 1-3.

Mellor J. 2006. Dynamic nucleosomes and gene transcription. Trends Genet 22: 320-329.

Mellor J, Dudek P, Clynes D. 2008. A glimpse into the epigenetic landscape of gene regulation. Curr Opin Genet Dev 18: 116122.

Meyer P, Saedler H. 1996. Homology-dependent gene silencing in plants. Annu Rev Plant Physiol Plant Mol Biol 47: 23-48.

Neil H, Malabat C, d'Aubenton-Carafa Y, Xu Z, Steinmetz LM, Jacquier A. 2009. Widespread bidirectional promoters are the major source of cryptic transcripts in yeast. Nature 457: $1038-1042$.

Noma K, Grewal SI. 2002. Histone H3 lysine 4 methylation is mediated by Set1 and promotes maintenance of active chromatin states in fission yeast. Proc Natl Acad Sci 99: 16438-16445.

Persson BL, Berhe A, Fristedt U, Martinez P, Pattison J, Petersson J, Weinander R. 1998. Phosphate permeases of Saccharomyces cerevisiae. Biochim Biophys Acta 1365: 23-30.

Rinn JL, Kertesz M, Wang JK, Squazzo SL, Xu X, Brugmann SA, Goodnough LH, Helms JA, Farnham PJ, Segal E, et al. 2007. Functional demarcation of active and silent chromatin domains in human HOX loci by noncoding RNAs. Cell 129: 1311-1323.

Samarsky DA, Ferbeyre G, Bertrand E, Singer RH, Cedergren R, Fournier MJ. 1999. A small nucleolar RNA:ribozyme hybrid cleaves a nucleolar RNA target in vivo with near-perfect efficiency. Proc Natl Acad Sci 96: 6609-6614.

Shukla A, Stanojevic N, Duan Z, Shadle T, Bhaumik SR. 2006. Functional analysis of H2B-Lys-123 ubiquitination in regulation of H3-Lys-4 methylation and recruitment of RNA polymerase II at the coding sequences of several active genes in vivo. J Biol Chem 281: 19045-19054.

Strahl BD, Allis CD. 2000. The language of covalent histone modifications. Nature 403: 41-45.

Taddei A, Hediger F, Neumann FR, Bauer C, Gasser SM. 2004. Separation of silencing from perinuclear anchoring functions in yeast Ku80, Sir4 and Esc1 proteins. EMBO I 23: 13011312.

Tresaugues L, Dehe PM, Guerois R, Rodriguez-Gil A, Varlet I, Salah P, Pamblanco M, Luciano P, Quevillon-Cheruel S, Sollier J, et al. 2006. Structural characterization of Set1 RNA recognition motifs and their role in histone $\mathrm{H} 3$ lysine 4 methylation. J Mol Biol 359: 1170-1181.
Uhler JP, Hertel C, Svejstrup JQ. 2007. A role for noncoding transcription in activation of the yeast $\mathrm{PHO} 5$ gene. Proc Natl Acad Sci 104: 8011-8016.

Vasiljeva L, Kim M, Terzi N, Soares LM, Buratowski S. 2008. Transcription termination and RNA degradation contribute to silencing of RNA polymerase II transcription within heterochromatin. Mol Cell 29: 313-323.

Volpe TA, Kidner C, Hall IM, Teng G, Grewal SI, Martienssen RA. 2002. Regulation of heterochromatic silencing and histone H3 lysine-9 methylation by RNAi. Science 297: 1833-1837.

Wang Y, Liu CL, Storey JD, Tibshirani RJ, Herschlag D, Brown PO. 2002. Precision and functional specificity in mRNA decay. Proc Natl Acad Sci 99: 5860-5865.

Weinberg MS, Villeneuve LM, Ehsani A, Amarzguioui M, Aagaard L, Chen ZX, Riggs AD, Rossi JJ, Morris KV. 2006. The antisense strand of small interfering RNAs directs histone methylation and transcriptional gene silencing in human cells. RNA 12: 256-262.

$\mathrm{Xu}$ N, Tsai CL, Lee JT. 2006. Transient homologous chromosome pairing marks the onset of $\mathrm{X}$ inactivation. Science 311: $1149-1152$.

Xu Z, Wei W, Gagneur J, Perocchi F, Clauder-Munster S, Camblong I, Guffanti E, Stutz F, Huber W, Steinmetz LM. 2009. Bidirectional promoters generate pervasive transcription in yeast. Nature 457: 1033-1037.

Zenklusen D, Vinciguerra P, Wyss JC, Stutz F. 2002. Stable mRNP formation and export require cotranscriptional recruitment of the mRNA export factors Yralp and Sub2p by Hprlp. Mol Cell Biol 22: 8241-8253. 


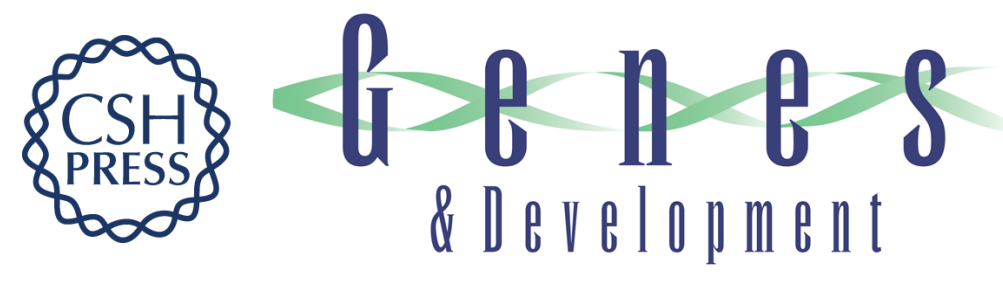

\section{Trans-acting antisense RNAs mediate transcriptional gene cosuppression in $S$. cerevisiae}

Jurgi Camblong, Nissrine Beyrouthy, Elisa Guffanti, et al.

Genes Dev. 2009, 23:

Access the most recent version at doi:10.1101/gad.522509

Supplemental
Material http://genesdev.cshlp.org/content/suppl/2009/06/18/23.13.1534.DC1

References This article cites 46 articles, 19 of which can be accessed free at:

http://genesdev.cshlp.org/content/23/13/1534.full.html\#ref-list-1

License

Email Alerting

Receive free email alerts when new articles cite this article - sign up in the box at the top

Service

right corner of the article or click here.

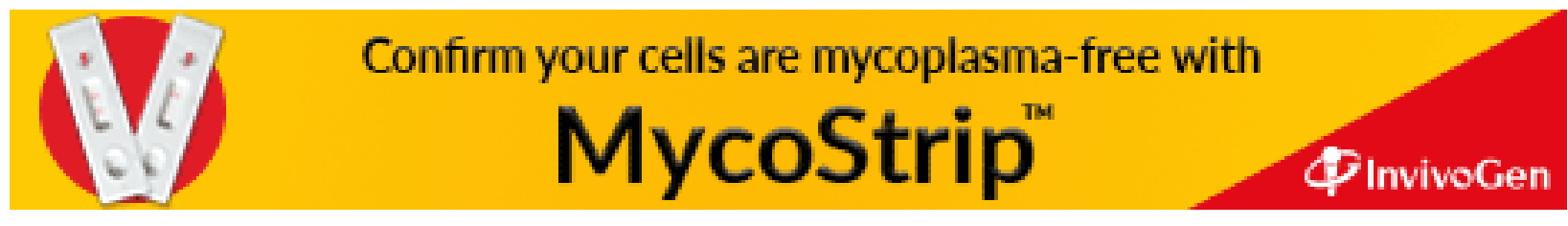

